\title{
ヒト組織フェノール硫酸転移醰素の遺伝的多型性
}

\author{
小澤 正吾 ${ }^{1}$, 清水万紀子 ${ }^{1,2}$, 松本 宜明 ${ }^{2}$, 福岡 正道 $^{2}$ \\ 加藤 貴彦 $^{3}$, 大野 泰雄 $^{1}$
}

\section{Genetic Polymorphism of Human Tissue Phenol Sulfotransferases}

\author{
Shogo OzaWA ${ }^{1}$, Makiko Shimizu',2, Yoshiaki Matsumoto ${ }^{2}$, Masamichi Fukuoka ${ }^{2}$, \\ Takahiko $\mathrm{KATO}^{3}$ and Yasuo $\mathrm{OHNO}^{1}$ \\ ${ }^{1}$ Division of Pharmacology, National Institute of Health Sciences, Tokyo; \\ ${ }^{2}$ Department of Clinical Pharmacology and Toxicology, Showa Pharmaceutical University, Tokyo; \\ ${ }^{3}$ Department of Public Health, Miyazaki Medical College, Miyazaki
}

\begin{abstract}
Summary: Three related forms of phenol sulfotransferase, thermostable ST1A2 and ST1A3 and a thermolabile ST1A5 are known to exist in human livers. Thermostable forms, whose activities are polymorphically distributed in human tissues, have been shown to mediate the bioactivation of carcinogenic $\mathrm{N}$-hydroxy aromatic amines as well as phenolic substrates. Variant forms of ST1A3 mRNAs (i.e. Arg213His and Met223Val) have been found in human livers. In a Japanese population, allele frequencies of ${ }^{213} \mathrm{Arg}$ and ${ }^{213} \mathrm{His}$ were 0.83 and 0.17 , respectively. No remarkable difference in $\left.{ }^{35} \mathrm{~S}\right] 3^{\prime}$-phosphoadenosine $5^{\prime}-$ phosphosulfate (PAPS)-dependent sulfation of p-nitrophenol was observed between recombinant ${ }^{213} \mathrm{Arg}$ - and ${ }^{213} \mathrm{His}-$ type ST1A3, although it was reported that ${ }^{213} \mathrm{His}$ homozygosity was associated with both lower (less than one-sevenths) $\mathrm{p}$-nitrophenol sulfation and thermolability in human platelets. The recombinant ST1A3 $\left.{ }^{(213} \mathrm{His}\right)$ did exhibit unstability at $45^{\circ}$ and $37^{\circ} \mathrm{C}$ as compared with ST1A3 $\left({ }^{213} \mathrm{Arg}\right)$. Liver cytosols from ${ }^{213} \mathrm{His}$ homozygotes did not always show low p-nitrophenol-sulfating activities. Different molecular mechanisms in sulfation polymorphism are suggested in livers and platelets of humans.
\end{abstract}

Key words: Sulfotransferase, Phenol sulfotransferase, Human, Liver, Platelet, Genetic polymorphism, cDNA expression, $E$. coli

\section{1. はじめに}

ヒト組織上清酵素である種々の硫酸転移酵素( sulfotransferase, 以下 SULT) は内因性基質, 薬物, 一般
化学物質の解毒, 排泄に重要な役割を果たすと共に, 基 質によっては代謝活性化反応を触媒する ${ }^{1)}$. SULT は ST1, ST2 など遺伝子スーパーファミリーを構成してい る2,3). ST1ファミリーに属し，フェノール性基質の硫

一おざわ しょうご

小澤正吾 : 国立医薬品食品衛生研究所, 薬理部, 室長, 薬学博士.

昭和 61 年, 東京大学大学院薬学系研究科博士課程修了. 昭和 61 年 63 年, 財) 癌研究会癌研究所化学療法センター 基礎部を経て, 昭和 63 年, 慶応義塾大学医学部薬理学教室·助手. 平成 7 年〜平成 9 年, 米国 National Center for Toxicological Research, Visiting Scientist. 平成 9 年, 国立衛生試験所(現·国立医薬品食品衛生研究所)薬理部, 主任 研究官. 平成 11 年より現職.

国立医薬品食品衛生研究所に来て以来，化学物質の代謝活性化を通じた毒性発現のヒト型検出系の開発，薬物代謝 酵素の多型性の分子機構の解析の研究に従事し現在に至る. 患者個人ごとの薬物療法の至適化の方策の確立等を目標 に, 薬物代謝を含め, 薬物に対する反応性を規定する遺伝子多型情報の収集・活用の研究プロジェクトの設立に関わ っている.

1国立医薬品食品衛生研·薬理厂158-8501 東京都世田谷区上用賀 1-18-1

2昭和薬大 ·薬物動態 ₹194-8543 東京都町田市東玉川学園 3-3165

3宮崎医大·公衆衛生 T889-1692 宮崎県宮崎郡清武町大字木原 5200 
酸抱合反応を触媒する酵素(PSULT)の活性には遺伝的 多型に基づく個体差が認められた 4,5)。実際，血小板な ぞ, 比較的少ない侵襲で得られる組織を用いて, 典型的 基質 $\mathrm{p}$-ニトロフェノールについて, 著しい個体差，お よび酵素活性の熱安定性が異なる酵素を有する亜集団の 存在が報告された ${ }^{6)}$ ．本酵素は癌原性アリルアミンの代 謝活性化反応を触媒することむ知られており7-9)，遺伝 多型による個体差の分子機構を知ることは重要である.

著者らは，以上の基質特異性を有する PSULT 分子種 について，米国人肝組織を検索することによりアミノ酸 置換を伴う遺伝子多型を 2 力所見い出した ${ }^{10)}$. それら のうち, 特に日本人にも認められる多型に着目し, 多型 の酵素分子種の性質を大腸菌内発現系を用いて解析し た ${ }^{11)}$. 本ミニレビューでは，著者らが得たPSULT の 多型酵素の性質に関する結果を中心に紹介するととも に, 肝および血小板におけるPSULT 多型について考 察を加える。

\section{2. ヒト組織 PSULT 活性の個体差}

ヒト組織に打ける硫酸抱合酵素の研究は, 当初, ドパ ミン等, 神経伝達物質の硫酸抱合活性の検索に着目して 展開された ${ }^{12)}$. 本活性を触媒するフェノール硫酸転移 酵素(EC2.8.2.1)の活性は比較的少ない侵襲で得られる 組織である血小板に検出され, 酵素学的性質がよく調べ られた ${ }^{13)}$ 。その結果, クロマトグラフィー上での挙動 や熱安定性, 基質特異性, 阻害剤に対する感受性を異に する少なくとも 2 種の PSULT が存在することが明ら 加にされた，その後これら PSULT は肝，脳，小腸粘 膜等に存在することが示された ${ }^{14)}$ 。また，これら分子 種は，免疫交差性はあるが，酵素学的には際立った性質 の差異が認められ，たとえば基質特異性の差異に基づい て, $\mathrm{p}$-ニトロフェノールを代表的基質とする P-PST ( $\mathrm{P}$ はフェノールの頭文字に因む)，ドパミンなど，フェ ノール性の水酸基と共にモノアミンを有する基質を代表 的基質とする M-PST (M はモノアミンの頭文字に因む) と呼ばれた1,3). また一方, 熱安定性の差異に着目して, P-PST はより熱安定であることから TS-PST (TS は “thermostable”), M-PST はより熱不安定であること より TL-PST (TLは“thermolabile”) とも呼ばれた1,3). 本稿では以後, 統一して前者をTS-PSULT, 後者を TL-PSULT と称する. 分子生物学的方法により, ヒト 肝 cDNA ライブラリー等を用いて, 2 分子種の TS PSULT (本稿では Yamazoe らの命名法2)による ST1A2， ST1A315) と称する）をコードする cDNA (ST1A3 cDNA を単離した別の研究室は P-PST-16) $\mathrm{HAST}^{177)}$ 打よび HAST2 ${ }^{18)}$ などと命名した)，TLPSULT (本稿では Yamazoe らの命名法による ST1A5 と称する)をコードする cDNA (HAST318)，TL PST ${ }^{19)}$ )
$\underline{\mathrm{A}}$

\begin{tabular}{ccc}
\hline $\mathrm{Km}$ & p-Nitrophenol & Dopamine \\
\hline$\sim 1 \mu \mathrm{M}$ & ST1A3 (TS-PSULT) & ST1A5 (TL-PSULT) \\
$\sim 10 \mu \mathrm{M}$ & ST1A2 (TS-PSULT) & \\
$\sim 1 \mathrm{mM}$ & ST1A5 & ST1A3 \\
\hline
\end{tabular}

$\mathrm{B}$ ST1A5 130 RNPKDVAVSYYHFHRMEKAHP ST1A3 130 --A---------Y--A-V--

Fig. 1 Properties of human thermostable (TS) - and thermolabile (TL)-phenol sulfotransferases (PSULTs) A: values of human TS-and TL-PSULTs for sulfations of $\mathrm{p}$-nitrophenol and dopamine

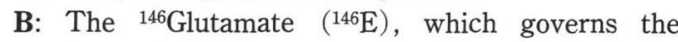
specificity of ST1A5 to dopamine and is found only in $\mathrm{ST} 1 \mathrm{~A} 5^{21)}$, is emphasized in a bold letter.

が単離された。さらに CDNAの異種細胞発現系を用い ることにより, 蛋白化学的および酵素学的方法で明らか にされた結果と分子生物学的方法で得られた結果とが統 一的に理解された ${ }^{20)}$ 。これら PSULT の性質の顕著な 差異につき Fig. 1 にまとめた. TL-PSULT (ST1A5), TS-PSULT (ST1A3)のアミノ酸の差異から，ドパミン 等のモノアミンを有する基質に対する特異性がコドン 146 のグルタミン酸で規定されることが明確に示され $た^{21)}$.

TS-PSULT と TL-PSULT 依存的活性について, 血 小板の酵素活性と肝の酵素活性が相関しているかどうか について知ることは, 血小板の酵素活性によって PSULT 活性形質の判定 (phenotyping) が可能かどうか を知る上で重要である．これを明らかにするには同一の ヒトからさまざまな組織を採取しなければならず簡単な ことではないが, 血小板-肝, 血小板-脳, 血小板一小腸 の間に, $\mathrm{p}$-ニトロフェノールの硫酸抱合活性の有意な 相関が認められた ${ }^{14)}$. それに対して，ドパミンの硫酸 抱合活性については前記の組織間に良好な相関が得られ なかったとされた。このようにTS-PSULT, TL PSULTの発現調節の機構は異なると思われた．これら のことから，少なくともTS-PSULT 活性の個体差には 遺伝因子が関係すると考元られ，著者らはヒト肝につい て, TS-PSULT の遺伝的多型の機構を調べる研究に着 手した.

\section{3. ヒト組織 TS-PSULT 活性の個体差の機構}

1）ヒト肝における TS-PSULT 分子種の発現と異型分 子種をコードする mRNA の存在

ヒト肝組織は, 米国 J. L. McClellan Memorial Veterans' Administration Medical Center, または米国 National Institute of Health, National Cancer Institute $\sigma$ 
Variant \#2 AA Variant \#1 AA ST1A3 AA ST1A3 CDNA

$\begin{array}{ll}\text { Variant \#1 } & \text { CDNA } \\ \text { Variant \#2 } & \text { cDNA }\end{array}$
Val

His

ValGlyArgSerLeuProGluGluThrValAspPheMetValgln 225

GTGGGGCGCTCCCTGCCAGAGGAGACTGTGGACTTCATGGTTCAG 675 HaeI I

Fig. 2 Alleleic variants of ST1A3 $\left({ }^{213} \mathrm{Arg} / \mathrm{His}\right.$ and $\left.{ }^{223} \mathrm{Met} / \mathrm{Val}\right)$

AA represents amino acids. Numbers for nucleotides begin with the "A" in the initiation codon, ATG. Underlined nucleotide sequences represent restriction enzyme recognition sites for HaeII (GCGC) and NlaIII (CATG).

Cooperative Human Tissue Network より得られた材料 を用いた. Poly $(\mathrm{A})+$ RNA を抽出後, cDNA を逆転写 酵素(reverse transcriptase; RT)を用いて調製した. ST1A2, ST1A3, ST1A5 cDNA に特異的な制限酵素認 識部位を用いた解析から，肝における主なPSULT mRNA 分子種は ST1A3 mRNA であると考えられた ${ }^{10)}$. 検索した 26 検体の肝組織の中には, PCR 産物について 予想された長さである $699 \mathrm{bp}$ を示さない検体は見い出 されなかった。 また，内部標準 DNA 断片を用いた競合 RT-PCR 法によって測定された ST1A3 mRNA のレべ ルと, $\mathrm{p}$ ニトロフェノール硫酸抱合活性との間に統計 的な有意な相関が認められた ${ }^{10)}$. さらに, ST1A3 cDNA の久を特異的に増幅しうる $3^{\prime}$-非翻訳領域のプラ イマーを用いることにより，各検体由来の ST1A3 cDNA の塩基配列を調べた ${ }^{10)}$. その結果, Fig. 2 に示 すように, ST1A3に異型酵素(Arg213His 打よび Met223Val) をコードする mRNA の存在をはじめて示 した ${ }^{10)}$.ささら Arg213His 抢よび Met223Val 多型を判 定しうるように, ST1A3 に特異的なイントロンプライ マーを用いてゲノム遺伝子を鋳型とした遺伝子型判定法 を確立し， 52 検体のヒト肝組織を用いコドン 213 の $\mathrm{Arg} / \mathrm{His}$, コドン 223 の Met/Val の多型の出現頻度を 調べた ${ }^{10)}$. 他の研究室でも Arg213His や Met223Val の 異型対立遺伝子の存在頻度が調べられた(Table I $)^{22,23)}$. 日本人では, 検索した 143 検体のなかには ${ }^{223} \mathrm{Val}$ 型異 型は認められず, 対立遺伝子の存在率で見ると ${ }^{213} \mathrm{Arg}$ 型は $0.87,{ }^{213} \mathrm{His}$ 型は 0.13 であった ${ }^{11)} .{ }^{213} \mathrm{Arg} / \mathrm{His}$ 多 型と肝の酵素活性の高低との関連は興味深いところであ るが, Table II に示したように, 必ずしも両者は明瞭 に関連していなかった。一方, Raftogianis らは 905 検 体ものヒト血小板の TS-PSULT 活性と, ${ }^{213} \mathrm{Arg} / \mathrm{His}$ 多型との相関を調べ, ${ }^{213} \mathrm{His}$ 型ホモのヒトの血小板の TS-PSULT 活性は他の遺伝子型をもつヒトの血小板の 酵素活性に比べて 7 分の 1 以下の活性しか示さなかっ たこと, 扰よび酵素活性の熱安定性が低かったと報告し た22).これらの結果より, 異型酵素の機能の差異を知 る必要があると思われたので, cDNAの大腸菌内発現 系を構築した。
Table I Allele frequencies of ST1A3 $\left({ }^{213} \mathrm{Arg} / \mathrm{His}\right)$ gene in Japanese, Caucasian and Nigerian populations

\begin{tabular}{lcc}
\hline & \multicolumn{2}{c}{ Allele frequency } \\
\cline { 2 - 3 } & ST1A3 $\left({ }^{213} \mathrm{Arg}\right)$ & ST1A3 $\left.{ }^{(213} \mathrm{His}\right)$ \\
\hline Japanese & 0.83 & 0.17 \\
Caucasian & 0.68 & 0.32 \\
Nigerian & 0.73 & 0.27 \\
\hline
\end{tabular}

Table II Range of hepatic p-nitrophenol-sulfating activities of individuals with ${ }^{213} \mathrm{Arg}$-and ${ }^{213} \mathrm{His}-\mathrm{al}-$ leles of ST1A3 genes

\begin{tabular}{cc}
\hline & $(\mathrm{pmol} / \mathrm{min} / \mathrm{mg}$ cytosolic protein $)$ \\
\hline${ }^{213} \mathrm{Arg} / \mathrm{Arg}(\mathrm{n}=28)$ & $280-2670$ \\
${ }^{213} \mathrm{Arg} / \mathrm{His}(\mathrm{n}=15)$ & $590-2280$ \\
${ }^{213} \mathrm{His} / \mathrm{His}(\mathrm{n}=9)$ & $680-2100$ \\
\hline
\end{tabular}

p-Nitrophenol sulfations in human liver cytosols were determined using $\left[{ }^{35} \mathrm{~S}\right] 3^{\prime}$-phosphoadenosine $5^{\prime}$-phosphosulfate as a sulfate donor.

\section{2）大腸菌内に発現させた野生型 $\left({ }^{213} \mathrm{Arg}\right.$ 型) および異 型 (213His 型) ST1A3 のアミノ酸配列 ${ }^{11)}$}

前述のように, ST1A3 をコードする cDNA や遺伝子 の配列はいくつかの研究室から報告された。それらの報 告にはコドン 213 について Arg, His をコードするもの が両方とも含まれており, SWISS-PROT のデータベー スでは「多型」としてリストされている. データベース 上, 少数の例外があるが, ${ }^{213} \mathrm{Arg} / \mathrm{His}$ 型分子種はコド ン 213 を除き同じアミノ配列を示した cDNA がもっと も多く收載されていた。今回著者らが単離した ${ }^{213} \mathrm{His}$ 型酵素をコードする cDNA も, コドン 213 以外は 213 $\operatorname{Arg}$ 型のアミノ酸と同一であり, ヒトに存在する ${ }^{213}$ His 型 ST1A3 のもっとも一般的な分子種と考えられ た.

3）大腸菌内に発現させた ${ }^{213} \mathrm{Arg}$ 型および ${ }^{213} \mathrm{His}$ 型 ST1A3 の酵素学的性質の比較 ${ }^{11)}$

${ }^{213} \mathrm{Arg}$ 型および ${ }^{213} \mathrm{His}$ 型 ST1A3 は共に Table III に 示す基質を効率良く硫酸抱合した. その結果, PSULT の代表的基質 $\mathrm{p}$-ニトロフェノールや2-ナフトールの 
Table III Sulfating activities toward substrates with phenolic and other structures by partially purified ST1A3 $\left({ }^{213} \mathrm{Arg}\right)$ and $\left({ }^{213} \mathrm{His}\right)$ expressed in Escherichia coli

\begin{tabular}{lcc}
\hline & ST1A3(213Arg) & ST1A3 $\left({ }^{213} \mathrm{His}\right)$ \\
\hline p-Nitrophenol & $10.2 \pm 1.2$ & $7.5 \pm 2.0$ \\
2-Naphthol/ & $3.8 \pm 1.9$ & $2.5 \pm 1.4$ \\
PAPS $^{\mathrm{a}}$ & $1.6 \pm 0.5$ & $1.5 \pm 0.1$ \\
Bisphenol A & $6.2 \pm 0.6$ & $6.9 \pm 0.1$ \\
Acetaminophen & $8.1 \pm 0.1$ & $9.4 \pm 0.3^{\mathrm{b}}$ \\
(+)-Isoproterenol & $4.0 \pm 0.4$ & $4.1 \pm 0.3$ \\
(-)-Isoproterenol & $5.8 \pm 0.3$ & $8.5 \pm 0.2^{\mathrm{b}}$ \\
Minoxidil &
\end{tabular}

In order to compare sulfating capacities of ST1A3 $\left({ }^{213} \mathrm{Arg}\right)$ and $\left({ }^{213} \mathrm{His}\right)$, sulfating activities were expressed as $\mathrm{nmol} / \mathrm{min} / \mathrm{nmol}$ ST1A3 after the determination of the amount of the allozymes used by Western blot analyses.

a $\left[{ }^{35} \mathrm{~S}\right]$ PAPS was used as a sulfate donor.

b $\mathrm{p}<0.001$

\section{p-Nitrophenol sulfation \\ ([ ${ }^{35}$ S]PAPS as a sulfate donor)}

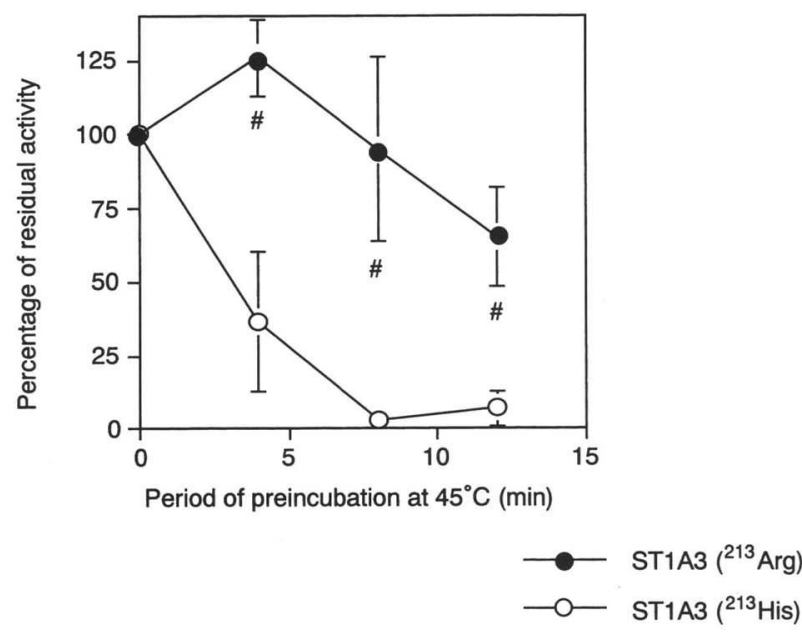

Fig. 3 Stability of bacterially expressed ST1A3 $\left({ }^{213} \mathrm{Arg}\right)$ and AT1A3 (213 His) after preincubation at $45^{\circ} \mathrm{C}$ for various time periods using $\left[{ }^{35} \mathrm{~S}\right] 3^{\prime}-$ phosphoadenosine $5^{\prime}-$ phosphosulfate (PAPS)-dependent p-nitrophenol sulfation as marker activities.

Closed and open symbols represent data for ST1A3 ${ }^{\left({ }^{213} \mathrm{Arg}\right)}$ and ST1A3 $\left({ }^{213} \mathrm{His}\right)$, respectively. \# implies $\mathrm{p}$ values $(\mathrm{p}<0.01)$ for statistically significant difference between data for ST1A3 ${ }^{\left({ }^{213} \mathrm{Arg}\right)}$ and ST1A3 $\left.{ }^{(213} \mathrm{His}\right)$ at the corresponding time period.

[35S] PAPS を硫酸基のドナーとした場合の硫酸抱合能 に関して ${ }^{213} \mathrm{Arg} / \mathrm{His}$ 型 ST1A3 の間には統計的に有意 な差異が認められなかった. 他の基質について, Table III に示すように有意差が認められたものもあるが，今 回測定した基質濃度では大きな差異ではなかった．それ に対し Fig. 3 に示すように, ${ }^{213} \mathrm{His}$ 型 ST1A3 は ${ }^{213}$
$\mathrm{Arg}$ 型に比し $45^{\circ} \mathrm{C}$ で速やかに酵素活性を失う熱不安定 な酵素タンパクであった。ごく最近，Raftogianis らは 肝の酵素活性と ${ }^{213} \mathrm{Arg} / \mathrm{His}$ 遺伝子型との関連を調べ， ${ }^{213} \mathrm{His}$ 型ホモの遺伝子型を有するヒト由来の肝の酵素は 血小板の場合と異なり，必ずしも酵素活性が低いとはい えなかった ${ }^{24)}$. この点, 著者らが肝について得た結果 と同様であった．ただし， ${ }^{213} \mathrm{His}$ 型ホモ遺伝子型を有す るヒト由来の肝の酵素は熱不安定ではあった ${ }^{24)}$ 。これ らの結果より, ${ }^{213} \mathrm{Arg} / \mathrm{His}$ は本酵素 ST1A3 分子種の熱 安定性を規定する多型であることが明らかになった。 た肝と血小板とでは，TS-PSULT の遺伝的多型の機構 に相違があることが強く示唆された.

\section{4. ヒト TS-PSULT の遺伝的多型性と疾病 感受性との関連}

TS-PSULT の発現レベルがもっとも高いと考えられ る肝組織に発現している主な分子種は, mRNA および 酵素分子種のレベルでST1A3であることが示され

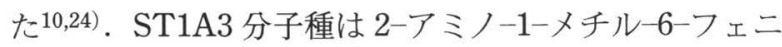

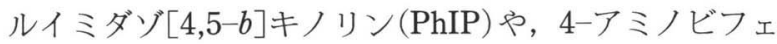
ニルの $\mathrm{N}$-水酸化体の代謝活性化能が高い8). PhIP は実 験動物に結腸癌を誘発し，加熱食品中の含量が最も高い 物質であることと, 食生活習慣から特に欧米人の大腸癌 との関連が考えられている．また，4-ABPはタバコの 煙に含まれ, 膀胱癌の原因物質の一つではないかと疑わ れている.バーベキューの機会を通じ肉類の焼け焦げの 摂取量が多く, 大腸癌発生率の高い米国において, $\mathrm{PhIP}$ の発癌リスク評価は大きな関心事である. PhIP の $\mathrm{N}$-水酸化酵素で, ヒト肝で主に発現している CYP1A2 と, 次いで起こるO-アセチル抱合反応や O 硫酸抱合反応による代謝活性化の形質と大腸癌感受性の 関連は特にアセチル抱合反応についてよく調べられてお り,アセチル化能の高いヒト(主にアリルアミンアセチ ル転移酵素 2(NAT2) 活性の高いヒト) は, 大腸癌感受 性が高いと考えられている25)。 また, 硫酸抱合酵素活 性については, Frameらにより TS-PSULT 活性が低 いヒトのほうが大腸癌感受性が高かったと報告され た ${ }^{26)}$. NAT2 とTS-PSULTの役割の差異の理由の一 つは，肝 NAT2 により生成した N-アセトキシ-PhIP が 循環血中でも安定に標的組織に運ばれうるのに対し, 肝 TS-PSULT により生成した N-スルフォキシ-PhIP は 非常に反応性に富むため不安定で標的組織に到達しえ ず27)，本酵素の活性が高いほど防御的に働くからでは ないかと提唱されている26).

\section{5.おわりに}

フェノール性水酸基を有する基質の硫酸抱合反応や, ある種の癌原性アリルアミンの $\mathrm{N}$-水酸化体, 発毛促進 
を目的に最近注目され，用いられているミノキシジルの 代謝活性化反応を触媒する TS-PSULT のうち, 肝での 主要分子種 ST1A3 について, アミノ酸置換を伴う多型

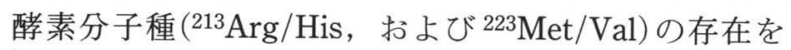
DNA および mRNA レベルで明らかにした10)。著者ら は次いで ${ }^{213} \mathrm{Arg}$ 型, ${ }^{213} \mathrm{His}$ 型 ST1A3 の大腸菌内発現酵 素を用い, ${ }^{213} \mathrm{Arg}$. His 型 ST1A3 の間にはその典型的 基質 $\mathrm{p}$-ニトロフェノールの硫酸抱合能に顕著な差異は 認められなかったこと, および ${ }^{213} \mathrm{His}$ 型 ST1A3 は不安 定な酵素分子種であることを明らかにした11)。これら の結果と, ${ }^{213} \mathrm{His}$ ホモと血小板 TS-PSULT 低活性との 関連が報告されたこと22), および肝の TS-PSULT 活性 は ${ }^{213} \mathrm{Arg} / \mathrm{His}$ とは明確な関連を示さなかったことから， 肝と血小板との間では TS-PSULT の遺伝的多型性の機 構は異なることが強く示唆された。このことは, TSPSULT の肝主要分子種 ST1A3 の癌原性芳香族アミン の代謝活性能と藏器癌の発癌感受性とを関連づける新し い遺伝多型の検索が必要であることを示しているかもし れない.

謝 辞: 本研究は, 慶應義塾大学医学部薬理学教室の加藤隆一 教授 (現·名誉教授), 山添康助教授 (現·東北大学教授) の癌 原物質の代謝活性化の研究に端を発しています。加藤先生, 山 添先生, 永田 清先生 (現・東北大学助教授) の各先生方のご指 導により，本稿の筆頭著者である小澤正吾は TS-PSULT をコ ードする ST1A2 およびST1A3 CDNA の単離を行いえたので あり, 深く感謝します。 また, 米国人肝組織の入手, 㧍よびを れらを用いてTS-PSULT の遺伝的多型性の研究の機会を米国 アーカンソー州 National Center for Toxicological Research (NCTR)に抢いて小澤正吾に与え，常に激励下さったDr. Fred F. Kadlubar (NCTR)抢よびDr. Nicholas P. Lang（J. L. McClellan Memorial Veterans' Administration Medical Center, Arkansas Cancer Research Center)に深謝致します.

\section{文献}

1) Falany, C. N.: Molecular enzymology of human liver cytosolic sulfotransferases. Trends Pharmacol. Sci. 12: 255-259 (1991).

2) Yamazoe, Y., Nagata, K., Ozawa, S. and Kato, R.: Structural similarity and diversity of sulfotransferases. Chem.Biol. Interact. 92: 107-117 (1994).

3) Weinshilboum, R. M., Otterness, D. M., Aksoy, I. A., Wood, T. C., Her, C. and Raftogianis, R. B.: Sulfotransferase molecular biology: cDNAs and genes. FASEB. J. 11: 3-14 (1997).

4) Pacifici, G. M., Temellini, A., Castiglioni, M., D’Alessandro, C., Ducci, A. and Giuliani, L.: Interindividual variability of the human hepatic sulphotransferases. Chem.-Biol. Interact. 92: 219-231 (1994).

5) Weinshilboum, R. and Aksoy, I.: Sulfation pharmacogenet- ics in humans. Chem.-Biol. Interact. 92: 233-246 (1994).

6) Van Loon, J. A. and Weinshilboum, R. M.: Human platelet phenol sulfotransferase: Familial variation in thermal stability of the TS form. Biochem. Genet. 22: 997-1014 (1984).

7) Kato, R. and Yamazoe, Y.: Metabolic activation and covalent binding to nucleic acids of carcinogenic heterocyclic amines from cooked foods and amino acid pyrolysates. Jpn. J. Cancer Res. 78: 297-311 (1987).

8) Ozawa, S., Chou, H.-C., Kadlubar, F. F., Nagata, K., Yamazoe, Y. and Kato, R.: Activation of 2-hydroxyamino-1-methy-6-phenylimidazo $[4,5-b]$ pyridine by cDNA-expressed human and rat arylsulfotransferases. Jpn. J. Cancer Res. 85: 1220-1228 (1994).

9) Chou, H.-C., Lang, N. P., Kadlubar, F. F.: Metabolic activation of the $\mathrm{N}$-hydroxy arylamines and $\mathrm{N}$-hydroxy heterocyclic amines by human sulfotransferase (s). Cancer Res. 55: 525-529 (1995)

10) Ozawa, S., Tang, Y-M., Yamazoe, Y., Kato, R., Lang, N. P., and Kadlubar, F. F.: Genetic polymorphisms in human liver phenol sulfotransferases involved in the bioactivation of N-hydroxy derivatives of carcinogenic arylamines and heterocyclic amines. Chem.-Biol. Interact. 109: 237-248 (1998).

11) Ozawa, S., Shimizu, M., Katoh, T., Miyajima, A., Ohno, Y., Matsumoto, Y., Fukuoka, M., Tang, Y.-M., Lang, N. P. and Kadlubar, F. F.: Sulfating-activity and stability of cDNA-expressed allozymes of human phenol sulfotransferase, ST1A3*1 $\left.{ }^{213} \mathrm{Arg}\right)$ and ST1A3*2 $\left.{ }^{213} \mathrm{His}\right)$, both of which exist in Japanese as well as Caucasians. J. Biochem. 126: 271-277 (1999).

12) Young, W. F., Jr., Okazaki, H., Laws, R. R., Jr. and Weinshilboum, R. M.: Human brain phenol sulfotransferase: Biochemical properties and regional localization. J. Neurochem. 43: 706-715 (1984).

13) Campbell, N. R. C., Van Loon, J. A. and Weinshilboum, R. M.: Human liver phenol sulfotransferase: Assay conditions, biochemical properties and partial purification of isozymes of the thermostable form. Biochem. Pharmacol. 36: 1435-1446 (1987).

14) Weinshilboum, R. M.: Sulfotransferase pharmacogenetics. Pharmacol. Ther. 45: 93-107 (1990).

15) Ozawa, S., Nagata, K., Shimada, M., Ueda, M., Tsuzuki, T., Yamazoe, Y. and Kato, R.: Primary structures and properties of two related forms of aryl sulfotransferases in human liver. Pharmacogenetics 5: S135-S140 (1995).

16) Wilborn, T. W., Comer, K. A., Dooley, T. P., Reardon, I. M., Reardon, R. L., Heinrikson, R. L., and Falany, C. N.: Sequence analysis and expression of the cDNA for the phenol-sulfating form of human liver phenol sulfotransferase. Mol. Pharmacol. 43: 70-77 (1993).

17) Zhu, X., Veronese, M. E., Sansom, L. N., and McManus, M. E.: Molecular characterisation of a human aryl sulfotransferase cDNA. Biochem. Biophys. Res. Commun. 192: 671-676 (1993).

18) Zhu, X., Veronese, M. E., Bernard, C. C. A., Sansom, L. N., and McManus, M. E.: Identification of two human brain aryl sulfotransferase cDNAs. Biochem. Biophys. Res. Commun. 195: 120-127 (1993).

19) Wood, T. C., Aksoy, I. A., Aksoy, S. and Weinshilboum, R. M.: Human liver thermolabile phenol sulfotransferase: cDNA cloning, expression and characterization. Biochem. 
Biophys. Res. Commun. 198: 1119-1127 (1994).

20) Veronese, M. E., Burgess, W., Zhu, X. and McManus, M. E.: Functional characterization of two human sulphotransferase cDNAs that encode monoamine-and phenol-sulphating forms of phenol sulphotransferase: Substrate kinetics, thermal-stability and inhibitor-sensitivity studies. Biochem. J. 302: 497-502 (1994).

21) Dajani, R., Hood, A. M. and Coughtrie, M. W. H.: A single amino acid, Glu146, governs the substrate specificity of a human dopamine sulfotransferase, SULT1A3. Mol. Pharmacol. 54: 942-948 (1998).

22) Raftogianis, R. B., Wood, T. C., Otterness, D. M., Van Loon, J. A., and Weinshilboum, R. M.: Phenol sulfotransferase pharmacogenetics in humans: Association of common SULTA1 alleles with TS PST phenotype. Biochem. Biophys. Res. Commum. 239: 298-304 (1997).

23) Coughtrie, M. W. H., Gilissen, R. A. H. J., Shek, B., Strange, R. C., Fryer, A. A., Jones, P. W. and Bamber, D. E.: Phenol sulphotransferase SULT1A1 polymorphism: molecular diagnosis and allele frequencies in Caucasians and African populations. Biochem. J. 337: 45-49 (1999).

24) Raftogianis, R. B., Wood, T. C. and Weinshilboum, R. M.:
Human phenol sulfotransferase SULT1A2 and SULT1A1: Genetic polymorphisms, allozyme properties, and human liver genotype-phenotype correlations. Biochem. Pharmacol. 58: 605-616 (1999).

25) Lang, N. P., Butler, M. A., Massengill, J., Lawson, M., Stotts, R. C., Hauer-Jensen, M. and Kadlubar, F. F.: Rapid metabolic phenotypes for acetyltransferase and cytochrome P450IA2 and putative exposure to food-borne heterocyclic amines increase the risk for colorectal cancer or polyps. Cancer Epidemiol. Biomakers Prev. 3: 675-682 (1994).

26) Frame, L. T., Gatlin, T. L., Kadlubar, F. F. and Lang, N. P.: Metabolic differences and their impact on human disease sulfotransferase and colorectal cancer. Environ. Toxicol. Pharmacol. 4: 277-281 (1997).

27) Kaderlik, K. R., Minchin, R. F., Mulder, G. J., Ilett, K. F., Daugaard-Jenson M., Teitel, C. H. and Kadlubar, F. F.: Metabolic activation pathway for the formation of DNA adducts of the carcinogen 2-amino-1-methyl- 6 -phenylimidazo $[4,5-b]$ pyridine (PhIP) in rat extrahepatic tissues. Carcinogenesis 15: 1703-1709 (1994). 